\title{
Environmental impact assessment and environmental management plan - a case study of magnesite and dunite mine, South India
}

\author{
E. V. MANOJ; V. PRASANNAKUMAR* \\ University College, Trivandrum, 695 034, India \\ *University of Kerala, Kariavattom, Trivandrum, 695 581, India: vprasan@vsnl.com
}

(Received December 2002 Accepted December 2002)

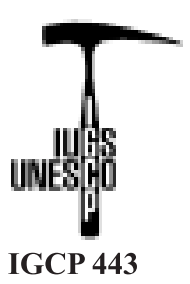

\begin{abstract}
The Chalk Hills region of Salem, Tamil Nadu, South India, has been the producer of magnesite of both calcination and refractory grades, for more than a century. Due to the vein type nature of the mineralisation, mining of this white carbonate of magnesium involves employment of men and deployment of heavy earth moving machines. The host rock, dunite, is also being mined as it is a commercially valuable by-product. The mining activity, comprising drilling, blasting (both primary and secondary), loading of waste, transport of over burden and crushing of ore is having considerable impacts on the environment. Dust generation, noise levels and ground vibration were monitored as part of the Environmental Impact Assessment (EIA). Control measures recommended on the basis of findings of EIA are being practiced. Review studies were conducted to gauge the healing effects following the implementation of the Environmental Management Plan (EMP). Implementation of the EMP points towards the sustenance of a clean, safe and congenial working environment in the mine and its precincts.
\end{abstract}

Key words: Magnesite mining, environmental impact assessment, environmental management plan, South India.

\section{Introduction}

Salem in Tamil Nadu, South India, is the hub of basic refractory industry in the country. Magnesite, the chief raw material for basic refractories as well as calcined Magnesia, is being mined from three large and several small mines located in Salem. The ultramafic complex of Salem spreads over an area of $30 \mathrm{~km}^{2}$ and is known as the Chalk Hills region. It is the repository of both refractory and non-refractory grades of magnesite. The deposits occupy numerous N-S trending small and moderately high hillocks (ranging in height from $5 \mathrm{~m}$ to $70 \mathrm{~m}$ from the mean ground surface). In addition to magnesite, dunite, one of the host rocks of mineralisation, is also being mined. Dunite, which contains about $45 \% \mathrm{MgO}$, is mainly used as a flux in steel manufacturing. It is used as a refractory in brick form and in bulk form and can also be used as railway ballast.

\section{Method of mining}

Complete mechanization of mining operations is not implemented in any of the mines because of the vein type mineralization. At present, a combination of both manual and mechanized mining methods is in use and hence can be aptly called as 'semi-mechanized' method. In semi-mechanized mining the mineralised zone is blasted by $83 \mathrm{~mm}$ diameter slurry explosives, charged in $115 \mathrm{~mm}$ diameter blast holes that are drilled using wagon drills. Bulldozers spread the blasted muck and magnesite lumps are collected manually. The leftover waste, comprising soil, dunite and peridotite of different grades of weathering are loaded into 35 MT capacity dump trucks using hydraulic excavators or wheel loaders. The waste is dumped at places ear-marked for spoil dumps on non-mineralized land. Fresh dunite, whenever encountered, is removed and stacked separately (Manoj, 2001). Hence, men working with 
crow-bars and sledge hammers are a common site in these mines, where Heavy Earth Moving Machines (HMM) like wagon drills, dozers, dumpers and hydraulic excavators are deployed. The absence of distinct overburden and mineral beds coupled with hard formations necessitates the employment of men and deployment of machines, simultaneously.

\section{Environmental impacts of mining}

Modern opencast mining involves a high degree of mechanisation of the operations. Deep hole drilling, blasting of formations and sizing by crushing of the mineral are essential activities in most large open cast mines. Heavy Earth Moving Machines (HEMM) are the essential features of all large open mines. Operation of HEMM, crushers and blasting causes environmental degradation from dust, noise and ground vibration.

\section{Dust pollution}

Mining environment is often encountered with major environmental pollution from dust. Drilling, blasting, haulage of HEMM, loading of ore/overburden by shovels, crushing and screening of ore and noxious fumes generated by explosives during blasting etc. lead to excessive production and accumulation of dust in the atmosphere. Excessive dust in the working environment can lead to pneumoconiosis, a general occupational lung disease, which depends on the quantity, quality and size distribution of air-borne dust, period of exposure and the susceptibility of the individual subjected to exposure. Specific names such as silicosis, asbestosis, and black lung disease have been used to indicate pulmonary diseases caused by dusts mainly composed of silica, asbestos, and coal respectively.

Dust can impede with the functioning of machines too. Engine life of machines, working in excessively dusty conditions, tends to be reduced. Efficiency of machines is also affected. Sensitive electronic parts of electronic equipment, especially the optical, sonic and heat sensors attached to automatic Fire Detection and Extinguishing Systems become less sensitive or malfunctional.

Agricultural crops cultivated near mining sites also are affected by dust deposited on the leaves. Crops like cotton and chilly are found to be affected by dust as the process of photosynthesis is interfered by partially obstructing the sunrays required for the process. This leads to a fall in the crop yield of about $20 \%$. Spoil dumps, devoid of vegetation allows blowing hot winds to lift dust from the exposed surface of land (Krishnakumar \& Manoj 1998).

\section{Noise pollution}

Noise emitted by machines in a mine during drilling, blasting, crushing and loading ranges from $64 \mathrm{dBA}$ to 115 dBA. The adverse effects are auditory and nonauditory on the health of the mineworker, the operating system of the mine and the physical objects.

\section{Effects of vibration}

Vibration is a reciprocating motion, which reverses itself twice every cycle. Vibration due to mining operations can be from three sources viz. tools and equipment in a mechanised mine, blasting of rock formations and movement of HEMM. Generally the vertical component of vibration is more severe. Below the $2 \mathrm{~Hz}$.frequency, the human body responds as a single mass. Between $4 \mathrm{~Hz}$. and $8 \mathrm{~Hz}$. considerable amplification of vibration is achieved and results in increased discomfort to the operators of hand held drills, dozer, shovel, tractor and dumper. Vehicle driven vibration can be detrimental to spinal health and cause digestive disorders to operators of the above equipments. Drivers' steering ability, foot pressure constancy, reaction time, and vision are affected by continuous exposure to vibration. High frequency (above $20 \mathrm{~Hz}$.) can cause head resonance. Frequency between $60 \mathrm{~Hz}$. and $90 \mathrm{~Hz}$. causes eyeball resonance. Intense, high frequency vibration of the hands ( $4 \mathrm{~Hz}$. to $250 \mathrm{~Hz}$.) may lead to nervous and circulatory damage known as 'Reynauld's Disease'.

One of the undesirable effects of rock blasting is ground vibration, which may result in structural damage. Ground vibrations are due to transmission of energy from explosive charge in waveform. These waves, called seismic or elastic waves depend on the elasticity of rocks. Some of the opencast workings are located near surface structures like residential buildings, schools, commercial buildings, hutments with large population etc. During rock blasting in a mine only about $20 \%$ to $30 \%$ of the energy released is utilized for rock fragmentation. The remaining energy is transmitted 
outwardly and can cause damage to surrounding surface structures (Arumugam \& Makesh 1998) While structures may not show any damage at a peak particle velocity (ppv) of $10-50 \mathrm{~mm} / \mathrm{sec}$ human response may show reduced comfort at $2 \mathrm{~mm} / \mathrm{sec}$. Human response to blast vibration and air over pressure is a concern that received little attention while sufficient details are available on the human response and annoyance due to air craft noise, road traffic or industrial noise. Mostly the annoyance has been referred to as motivated by political and social reasons on the basis of immediate response to the blasts (Raina et al 2002). Various levels of perception of ground vibration are presented in Table 1.

Table 1: Levels of perception of ground vibration

\begin{tabular}{|c|l|}
\hline $\begin{array}{l}\text { Approximate } \\
\text { Vibration (ppv) }\end{array}$ & Level / Degree of Perception \\
\hline $0.01 \mathrm{~mm} / \mathrm{s}$ & Not felt \\
\hline $0.15 \mathrm{~mm} / \mathrm{s}$ & Threshold of perception \\
\hline $0.35 \mathrm{~mm} / \mathrm{s}$ & Barely Noticeable \\
\hline $1.00 \mathrm{~mm} / \mathrm{s}$ & Noticeable \\
\hline $2.20 \mathrm{~mm} / \mathrm{s}$ & Easily Noticeable \\
\hline $6.00 \mathrm{~mm} / \mathrm{s}$ & Strongly Noticeable \\
\hline $14.00 \mathrm{~mm} / \mathrm{s}$ & Very Strongly Noticeable \\
\hline
\end{tabular}

\section{Deforestation and loss of surface soil}

Cleaning the surface of vegetation precedes any opencast mining operation. Felling of trees leads to changes in the weather pattern besides threatening the life of fauna living in it. It can lead to local increase in the diurnal temperatures in addition to losing aesthetic beauty. The humus rich surface soil is to be scraped off before planning a box-cut and drilling blast holes. The invaluable topsoil is sometimes transported to the spoil dumps and is lost forever due to burial under the consequently produced mining spoils which are largely infertile (Krishnakumar \& Manoj 1998).

\section{Environmental impact assesment}

The impacts of opencast mining were initially assessed in the Red Hills magnesite and dunite mine (largest among the seven) of Burn Standard Co.Ltd. (Government of India undertaking), having integrated basic refractory and calcinations plants and having the largest lease hold land of 765 hectares in the Chalk Hills region. This captive mine of BSCL, located about 12 $\mathrm{km}$ from Salem, the nearest town, caters to the major needs of the refractory and calcination plants. In order to assess the environmental impact of this mine, seasonal variation in the levels of dust, noise and ground vibration, were monitored during three seasons.

\section{Dust}

Dust generation at drilling, blasting, loading and haulage points were determined using Gravimetric Samplers. Free settling dust was collected using special dust collecting vessels. As secondary crushing of magnesite is done at the plant, the dust generated at the crushing and screening plant has been excluded from this study. The results of dust monitoring are given in Table 2.

Table 2: Dust level (in mg/M3) during different seasons

\begin{tabular}{|l|c|c|c|}
\hline $\begin{array}{l}\text { Locations of Dust } \\
\text { Collection }\end{array}$ & Winter & Summer & Monsoon \\
\hline $\begin{array}{l}\text { Drilling (wagon } \\
\text { drill) }\end{array}$ & 6,8 & 7,8 & 6,5 \\
\hline $\begin{array}{l}\text { Drilling (jack } \\
\text { hammer) }\end{array}$ & 4,2 & 4,7 & 3,2 \\
\hline $\begin{array}{l}\text { Blasting (deep } \\
\text { hole) }\end{array}$ & 6 & 6,2 & 5,8 \\
\hline $\begin{array}{l}\text { Blasting(shallow } \\
\text { hole) }\end{array}$ & 5,5 & 6 & 5 \\
\hline Loading (shovel) & 6,8 & 7,3 & 6 \\
\hline Haul Road & 5,1 & 6,2 & 4,8 \\
\hline Dozer & 8,35 & 8,5 & 6,5 \\
\hline
\end{tabular}

\section{Noise}

Noise level was monitored using audiometers with provision to read the digitally displayed values instantaneously. The noise level measurements were taken at a distance of $15 \mathrm{mts}$. from different machines operated in the mine. Readings were also taken in the operator's cabin for shovel and dumper. Results of the measurements are given in Table 3.

\section{Vibration}

Ground vibration was measured at the time of heavy blasting at different locations inside the mine (Table. 4). 
PRASANNAKUMAR V.; MANOJ. E. V. Environmental impact assessment and environmental management plan - a case study of magnesite and dunite mine, South India

Highly sensitive vibrometers were set on the ground in the vicinity of nearest structures from the blast site. Ground vibration due to heavy blasting was measured in the adjacent villages also.

Table 3: Noise level data

\begin{tabular}{|l|c|c|}
\hline \multirow{2}{*}{\multicolumn{1}{|c|}{ Equipment }} & \multicolumn{2}{c|}{ Noise level in dBA } \\
\cline { 2 - 3 } & In cabin & At $15 \mathrm{~m}$. \\
\hline Front End Loader & 92 & 85 \\
\hline Dozer & 115 & 105 \\
\hline Drills (wagon) & - & 110 \\
\hline Drill(jack hammer) & - & 112 \\
\hline Hydraulic Excavator & 85 & 80 \\
\hline Dumper & 95 & 90 \\
\hline Heavy Blasting & - & $123($ At $150 \mathrm{~m})$ \\
\hline
\end{tabular}

Table 4: Ground Vibration

\begin{tabular}{|l|c|c|}
\hline $\begin{array}{c}\text { Distance of Measurement \& } \\
\text { Nature of Structure }\end{array}$ & $\begin{array}{c}\text { Frequency } \\
\text { (Hz.) }\end{array}$ & $\begin{array}{c}\text { Peak particle } \\
\text { velocity }(\mathrm{mm} / \mathrm{sec})\end{array}$ \\
\hline 200m, Compressor Shed & $43 \mathrm{~Hz}$. & 2,57 \\
$550 \mathrm{~m}$, Village & $45 \mathrm{~Hz}$. & 1,9 \\
150m, Adjacent Mine Pit & $42 \mathrm{~Hz}$. & 3,95 \\
100m, Foreman's Office & $40 \mathrm{~Hz}$. & 10,55 \\
\hline
\end{tabular}

\section{Environmental management plan}

The systematic analysis of various pollution parameters has indicated that the environmental impacts of dust, noise and ground vibration are above the desirable limits and can adversely affect the mine workers in the long run. Consequent on these findings, the management adopted and implemented several corrective measures to minimise the impact.

As a precaution to check dust pollution, systematic sampling and analysis of air inside the mine was initiated and emission of dust was minimised. The exposure of workers to breathable dust were limited to such extend that the limits are not harmful to their health. Dust levels during drilling were reduced by introducing wet drilling and providing dust extractors to wagon drills. Dust respirators were supplied to drillers and HEMM operators where the air-borne breathable dust could not be brought below $3 \mathrm{mg} / \mathrm{M}^{3}$. Haul roads and loading points were sprinkled with water and slopes of the spoil dumps were planted with tree saplings to prevent dust rising during dry winds. Adoption of these programmes reduced production, emission and inhalation of dust (Table 5).

Table 5: Dust level (mg/m3) after implementation of EMP

\begin{tabular}{|l|c|c|c|}
\hline \multicolumn{1}{|c|}{$\begin{array}{c}\text { Locations of Dust } \\
\text { Collection }\end{array}$} & Winter & Summer & Monsoon \\
\hline Drilling (wagon drill) & 3,5 & 3,8 & 2,9 \\
\hline Drilling (jack hammer) & 3,2 & 3,5 & 2,8 \\
\hline Blasting (deep hole) & 6 & 6,2 & 5,8 \\
\hline Blasting(shallow hole) & 5,5 & 6 & 5 \\
\hline Loading (shovel) & 3,3 & 4,3 & 3 \\
\hline Haul Road & 3,1 & 3,2 & 2 \\
\hline Dozer & 5,35 & 5,6 & 3,5 \\
\hline
\end{tabular}

Control of noise in mines can be achieved by reducing the sound at source or by interrupting the path of noise. The best approach would be to control noise at the source. There are several general practices on controlling noise. They are designing of the machine, its proper installation, periodic maintenance, lubrication etc. Damping impact noise and noise insulation by sound absorbing materials and properly covering the machine with enclosure/ bonnet etc helps to control noise at source. Interrupting the path of noise comprises erection of acoustic barriers to prevent its propagation. Noise can be prevented from reaching surrounding places by creation of green belts around the mine complex. In addition to the noise reducing techniques the worker can be protected from noise by controlling the time of exposure of a worker to the noise and by providing earplugs and earmuffs to the men working under hazardous noise levels.

For frequencies greater than $20 \mathrm{~Hz}$, the threshold limit of ground vibration (no damage level) for safety of structures has been found to be $50 \mathrm{~mm} / \mathrm{sec}$. (ppv). In case of frequency less than $20 \mathrm{~Hz}$ the amplification of the maximum permissible limit of ground vibration or 'safe value' for the structures is $12.5 \mathrm{~mm} / \mathrm{sec}$. Major factors that control ground vibration are the type and quantity of explosive charge used, distance from the charge/blast site to the point of observation, geological parameters of the formation, physicomechanical characteristics of the rock that transmits the vibration and blast geometry including depth, inclination, spacing and burden of rocks (Arumugam \& Makesh 1998). Use of safe maximum charge per delay, hole to hole delay, 
adoption of non electric ('nonel') initiation system, adoption of deck-charging, use of sequential blasting machine, effective muffling of the holes etc. were a few of the measures undertaken to minimise the ground vibration.

\section{Conclusion}

The environmental impact analysis has revealed hazardous levels of dust and noise prevailing at the various work spots in the mine. Implementation of environmental management plan has helped to reduce the dust and noise levels below the undesirable limits. Reduction of noise at source, interruption of noise in its path of propagation and protection of the receiver from high noise levels has further improved the working environment. Ground vibration was well within the limits at the time of EIA since proper blasting practices were being used. The humus-rich surface soil, scraped and removed from the surface, prior to opening of new pits, is conserved and is used for developing green belts on spoil dumps. As EIA and EMP have been made statutory requirements for starting new mining ventures as well as for existing mines, (at the time of renewal of mining plans) measures to prevent environmental degradation have become a subject of priority with the mine managements. Sequential Blasting Machine and Nonel Shock Tube Detonators would make it possible to exploit some of the rich mineral deposits which could not be mined otherwise due to environmental concerns. Apart from controlling the environmental degradation in the mine the EIA and EMP have helped to improve the life of lots of people inhabiting nearby villages.

Acknowledgement

We are grateful to the management of Burn Standard Co. Ltd, Salem, for sharing the data of EIA.

\section{References}

Arumugam S. \& Makesh S. 1998. Control Measures on Noise and Vibration in Mines. Proceedings of the workshop on 'Basic Need for Creating and Sustaining a Clean, Safe and Congenial Work Environment'. Directorate General of Mines Safety-Tamilnadu \& Kerala. Mines Safety Association. Salem, 7-10.

Krishnakumar R.A. \& Manoj E.V. 1998. Afforestation in Mines. Proceedings of Workshop on 'Basic Need for Creating and Sustaining a Clean, Safe and Congenial Work Environment' Directorate General of Mines Safety-Tamilnadu \& Kerala Mines Safety Association. Salem, 13-14.
Manoj E.V. 2001. A Mechanization Plan for Improving Quality and Productivity in Veiniferous Magnesite Mines. Mining Engineers' Journal, .3, 25-28.

Prasad S.D. \& Rakesh. 1999. Legislation in Indian Mines: A Critical Appraisal. Tara Book Agency, Varanasi,

Raina A.K., Halder A., Ramulu M., Choudhury P.B., Palroy P. \& Jethwa J.L. 2002. Awareness of Blast Induced Ground Vibration and Air-Over Pressure in Opencast Mines in India, to Mitigate Human Annoyance and Complaints-A Need of the Hour." Mining Engineers' Journal, 3, 14-17. 